\title{
Dark Humor, Irony, and the Collaborative Narrativizations of Regional Belonging
}

\section{Juha Ridanpää}

\section{ABSTRACT}

In literary geography there is a relatively long history of studying regional narratives, but less focus has been placed on how senses of spatial belonging and identity become actualized through the reception and re-interpretations of regional literatures. This paper discusses how Meänkieli-speaking minorities in northern Sweden narrativize their shifting spatial identities through regional literature, i.e. Mikael Niemi's successful humorous novel Populärmusik frain Vittula (2000). The paper approaches the literary work simultaneously through the critical analysis of the book's content, readers' interpretations and the interconnections between the author, the reader and wider social circumstances. The analysis is based on group discussions conducted in northern Sweden between September 2015 and February 2016. As an outcome of these discussions, it emerged how different manners of approaching the irony and dark humor of Niemi's book divide people's senses of regional belonging and launch the alternative, confronting conceptions of "who we are".

Key Words: literary geography, minority languages, regional identity, narrative, irony.

Ridanpää, J. (2019). Dark Humor, Irony, and the Collaborative Narrativizations of Regional Belonging. GeoHumanities, 5(1), 69-85. 


\section{INTRODUCTION}

Public interest in regions and regionality has risen substantially during recent years. For instance, in the United Kingdom regions and regional systems are routinely used and utilized as bureaucratic components for the purposes of national politics and policies (see Paasi and Metzger 2017). When regions are understood as institutional constructions, there is a certain flavor of artificiality perceptible, while for people living in the region the very essence of regionality may be a crucial part of their identity. Emotions such as the sense of spatial belonging or the sense of being-at-home are often manifested on the scale of regions, emotions that are often processed against various forms of narratives. It can also be understood that spatial identity comes into existence in narratives or that spatial identity is the equivalent of narrative. However, particular forms of (spatial) narratives have an important role in terms of how people conceive themselves, make categorical separation from 'others', and by that means bring 'we' into being.

Narrativizing can be understood as a simple communicative tool through which people make sense of essentially everything. Narrativized identities, as scripts of past events, become established in different ways, through different forums. Story-telling is an everyday practice in which self-understandings are negotiated repeatedly, in a semi-conscious manner, while a work of regional literature, among other written forms of narratives, represents a (historical) document in which the conceptions of 'us' are reflected, conveyed, constructed and maintained. In this paper the purpose is to scrutinize the interconnections between two forms of regional narratives: literary narratives and local stories. The paper dissects how literary narratives and individual human narratives become collaboratively entwined as well as how they together constitute alternative conceptions of "who we are". At the same time, the interconnections between the author, the reader and wider societal discourses are analyzed.

The studied case concerns how the marginal(ized) identity of Tornedalen region, located in northern Sweden, is narrativized in Mikael Niemi’s Populärmusic från Vittula (Popular Music from Vittula) 2000, and how the novel is received by local people. Specific focus is placed on how varying manners of approaching literary irony and dark humor, as complicate forms of communication, divide people's conceptions of their regional belonging. In the same vein the purpose is to illustrate and analyze the 'power' of literature in the process of spatial identity construction. The research material consists of Niemi's novel and eight group discussions with local cultural workers, conducted in Tornedalen between September 2015 and February 2016. 
The main focus is on the evolving and also confrontational way that people narrativize their sense of regional belonging through literature.

\section{NARRATIVIZING REGIONS WITH LITERATURE AND HUMOR}

The history of regional geography can be traced back to Alfred Hettner's (1907) argument on how, rather than systematic chorological studies, the main core of geography should be the study of regions. In early geographical studies of literature, it was discovered how fluently novelists were capable of describing regional 'personalities' and how, by that means, literature provides an invaluable research 'database' for geography (Gilbert 1960). Regions were perceived as individuals with their own unique features and specific 'personal' characteristics, while regionalists were considered to be specialists who were able to expose the true character of the region to those who had never visited or even heard about the place in question (Paterson 1965, 146). For a long time, it has been argued that characteristic of all regional literature is its focus on man's relation to his environment and the "everyday life of a locality" (Darby 1948, 426), and therefore how geography and literature are inextricably linked.

When perceived from a more socially critical point of view, literature functions as a type of sociocultural institution which produces and offers ideals and criteria about spatial identity, stories about on what grounds 'we' are different from 'them' (Noxolo and Preziuso 2013; Ridanpää 2014). Literature situated in a certain region is not only about reflecting and describing regional identity, but also functions as an active participant in the processes whereby regional identities are socially constructed and mediated into people's regional consciousness (Paasi 1984, 114). By that means the very idea of a region as an individual actor as well as regional consciousness are constructions which become established through literary narrations. In the same vein Tomaney $(2007,355)$ has emphasized the storied nature of regional identity and argued that "collective identities are not pregiven, but draw on discourses to which intellectuals, cultural producers, and political leaders contribute".

Although individual human emotions are essential elements when discussing the narratives of regional belonging, it is also highly important to pay attention to the social context within which narratives become constructed and especially to how they turn into the key constituents of the narratives themselves. In his article 'Beyond text and literature', published in Environment and Planning D: Society and Space in 1984, John Silk criticized what he saw as excessively humanistic geography for its overly narrow definition of 'literary' and thus expanded the discussion towards 
Marxist analysis, "which has the goal of exposing and combating bourgeois ideology" (1984, 151). One interesting part of Silk's paper was how he approaches the link between writers, texts and readers by reformulating the classic communication model between sender, message, and receiver, and including the context within which this process of communication takes place. The context is highly important in Silk's model and specific attention now is paid to those 'other' contexts beyond 'literary': economic, political and social.

Silk's (1984) model is at the same time very simple and highly complicated, or at least nuanced and multidimensional. It illustrates how the chain between the writer, the text and the reader, as well as their contexts, can be interpreted in multiple ways. Silk explains how employing different terms is needed since some terms are more appropriate for certain approaches; whether we understand the relationship between the text and reader as an act of reading, consuming or becoming affected by literature, is a matter of one's theoretical perspective. Silk explains how in structuralist interpretations writers are understood as passive components of social structures through which specific context works, while in culturalist interpretations writers are perceived to have a more active role within certain contexts. In addition, different terms indicate the dialectical nature of the relationships involved. Writers are always active agents consciously shaping "the text in terms of plot, literary devices, characterisation, and the like" (167), they use and allude to previous literary works, drawing upon and modifying linguistic resources, and making "use of themes which cannot fail to be in some way influenced by the wider social, economic, and political context within which the writer is working” (167). Yap (2011) for her part has criticized the way how the communication chain between author, text and reader has been approached in geographical studies of literature. According to Yap, texts are often approached as static representations and readers as passive and homogenous. Correspondingly, Yap underscores that more emphasis should be paid to readers' responses and especially to their heterogeneity.

Furthermore, the meanings of the interconnections between writer, text, reader and various forms of contextuality change if we understand regions as relational (see Jones 2009; Saunders and Anderson 2015; Paasi and Metzger 2017). In the case of regions, relationality refers to the idea that spatial identities do not construct, happen or take place in specific cartographical locations but rather come into existence on the level of interactions between various actors and cultural and social institutions. However, although in recent studies the relationality of storytelling has been underscored (Cameron 2012), according to Tomaney, literary regional narrations may challenge those “advocates of the 'relational region' who see places as simply the local articulation of global flows and who present any concern with local culture and identity as 
atavistic and archaic" (2007, 356). There are several everyday 'attributes', such as childhood and mundane landscapes, social networks, generational viewpoints, cultural traditions, mobility and media, through which spatial identification and its existential dimension become fastened to smaller-scale localities and municipalities (Vainikka 2012, 600). Tomaney considers poetry in particular "a means of developing narratives of local and regional identity in ways which transcend the dichotomies with which social scientists in general-and geographers in particular-perennially struggle" $(2007,356)$.

People make sense of spatial belonging, of who they are, what kinds of communities they belong to, through stories; stories may also be used to narrativize their position in relation to others, that is, to emplot people's spatial bearings and identities (Prokkola and Ridanpää 2011; Rycroft and Jenness 2012; Rose 2016). Although in the case of regionalism, narratives have a certain stickiness in terms of their content, as Tomaney has implied, regional identities are also relational and are constantly renegotiated through the communication chains between the author, the text, the reader and the totality of the contextuality involved. Regional literatures produce narratives and textual spaces that do not have a finite endpoint, but rather remain in motion, keep on happening (see Hones 2014).

In narrative approaches the world is comprehended as 'a narration' that becomes meaningful through the processes of reading and writing at the moment that the written information becomes shared. Hones (2008) has conceptualized this moment as an "event". Narrations work as linguistic strategies through which (minority) identities become established (Gilmartin and Migge 2015), which in the context of regionalism refers to both individual and collective expressions of feelings "at home" (Tomaney 2015, 508). In the 1970s Tuan described this incipient regional consciousness as shared inchoate feelings: "Shared feelings may develop spontaneously into, or can be deliberately made into, shared lore and a shared body of explicit knowledge" (Tuan 1975, 159).

In geographical studies of narratives and identities, the role of humor has been more or less a dismissed topic. Humor is a rhetoric device which is used in story-telling in everyday communication and interaction, mostly unconsciously (Norrick and Chiaro 2009). In studies where participant observation of focus groups has been used, it has been noticed that humor functions as a communicative mechanism through which shared identities become established (Terrion and Ashforth 2002). Humor is an inseparable part of narrativization (see Knuuttila 1992); people use humor, both as a standpoint and as a rhetoric device, in the process of organizing, representing and reasoning their personal experiences, as well as in reflecting their identities. Laughter, a bodily performance often associated with humor, is often used almost 
reflexively during story-telling in order to add certain emotional nuances to the communicated meanings. Within social groups humor increases the sense of affinity and belonging, the "wefeeling” (Delph-Janiurek 2001; Terrion and Ashforth 2002; Vucetit 2004); in terms of group dynamics, "joking is not something done by existing subjects, but how the comic constitutes subjectivity" (Atluri 2011, 199).

Humor thus possesses a shared social purpose in fostering group cohesion and social bonding, as well as in creation and preservation of shared identities (Davies 1990; Palmer 1994). Respectively, conversational joking develops relational identities (Boxer and Cortés-Conde 1997). In addition, humor functions not only as a narrative 'tool' but also as a wider perspective through which regional narratives as well as their counter-narratives are told and perceived. Although different forms and characteristics of humor are culture-specific, according to Boxer and Cortés-Conde $(1997,292)$ the social function of humor in group identity formation seems to cross cultural boundaries.

It is important to underscore that forms of humor are various, and their appropriateness for identity formation vary notably. For instance, dark humor and irony are tricky forms of humor and using them with a goal of establishing affinity, belonging and "we"-feeling is extremely complex. With using the example of the challenges of remembering and memorializing the violent past of Bosnia-Herzegovina's, Anna Sheftel (2012) argues how dark humor functions as a subversive form of counter-memory, that allows expressing dissent from dominant narratives. On the other hand, if (and often when) dark humor is not understood, its impact is easily a negating one, especially in the case of sensitive topics. In similar manner, irony becomes suppressive in a situation when it is not understood, when its target becomes embarrassed and humiliated (Hutcheon 1994, 40-3). According to Katherina Barbe:

Some people are more "irony-competent" than others. Irony emerges as a concept open to individual interpretation, leaving ample room for error. But who is to judge the "error" in interpretation? Even though irony appears embedded in the language speakers/hearers share, not every speaker/hearer decodes each instance of irony in a uniform way. (Barbe 1995, 172)

Because of this "room for error", that irony encases, ironic literature, instead of establishing a coherent sense of "we", easily launches conflicting identity narratives and various forms and interpretations, depending on the reader's personal sense of humor as well as the sociopolitical and cultural background. In case of marginal regions, irony can be used for emancipatory 
purposes, for rewriting the hegemonic narratives (see Ridanpää 2010), but for regionalist purposes its use may also be tricky. Irony sometimes comes close to lying, or hard to separate from it (Barbe 1995, 123-26), while regionalist writers are always expected to describe the local life as authentically as possible, "as it is". "Who is to judge the 'error' in interpretation?", is indeed a good question, which lifts up the essential point that in case of regional identities the focus should always be at heterogeneity.

\section{THE SOCIOPOLITICAL HISTORY OF TORNEDALEN}

In order to understand the different meanings concerning emotional attachments to a region and their narrativization, it is highly important to be somewhat acquainted with the region's sociopolitical discourses and their history. This becomes clearly evident when Mikael Niemi's breakthrough novel Populärmusik fran Vittula is read against the backdrop of Tornedalen's social history. Tornedalen is a marginalized region, in several ways, with a history reaching back to the Finnish War between the Kingdom of Sweden and the Russian Empire in 1808-1809. After the war Finland was incorporated into Russia and the new border between Sweden and Russia was situated on the Torne River, straddling a culturally coherent Finnish-speaking region. Regarded as an ethnically inferior population, the 'other', compared to the Swedish-speaking majority, and considered a threat to national security, the Finnish-speaking minority on the Swedish side of the Torne Valley was subject to powerful linguistic and cultural integration pressures from the late 19th century until the middle of the 20th century (see Elenius 2001).

This reverberated in various state-driven social practices through which the process of othering was put into action. For instance, speaking Finnish in schools was forbidden during the first half of the $20^{\text {th }}$ century (see Júlíusdóttir 2007: 41). Correspondingly, during the same era Swedish anthropologists tried their best to prove the inferiority of the Finnish race (Heith 2012). The hostility continued throughout the early $20^{\text {th }}$ century until relations with an independent Finland improved (Hult 2004, 188). During the years of 'Swedification' Finnish heritage became something to be ashamed of, something that needed to be hidden; for instance, exchanging Finnish surnames for Swedish ones became highly popular. At the same time, the number of Finnish speakers decreased remarkably (see Prokkola 2009, 28).

The 'ethnic renaissance' of the late 20th century resulted in a major change in local social selfesteem in the region, and a new impetus to preserve the region's culture and language has led to increased activity on the part of this minority group (see Winsa 2005). "Meän”, a dialectal word 
meaning "our", evolved into the keyword around which all this new cultural and social activity became entwined. The organization Svenska Tornedalingars Riksförbund (STR-T) was established in 1981 for the revitalization of Tornedalian culture and language. In addition, there are several individuals, such as the politician Ragnar Lassinantti (1915-1985) and culture activist/novelist Bengt Pohjanen, who have worked in different roles towards revitalizing language and local identity. The language spoken in the region was not called Finnish, but "Meänkieli”, “our language”. In Finland Meänkieli is usually defined as a dialect of Finnish, while in Sweden, as a result of hard identity work, Meänkieli achieved official status as a minority language in 2000, the same year Mikael Niemi's Populärmusik, fran Vittula was published. What is characteristic of Meänkieli is the extensive use of h-sounds, the loaning of Swedish words and certain form of regression compared with Finnish spoken in today's Finland (see Vaattovaara 2009). According to Ethnologue: Languages of the World, there are approximately 30000 Meänkieli speakers on the Swedish side of Tornedalen, but the exact number of speakers is highly difficult to estimate, since people are often uncertain whether the language they use can actually be defined as Meänkieli or not. In addition, opinions are varying whether the dialect spoken on the Finnish side of Tornedalen should be also called Meänkieli or not.

Populärmusik, från Vittula was an immediate best-seller in Scandinavia and was translated into several languages, winning several awards, including Sweden's prestigious August Prize for literature. Six years after its publication, the book had already sold almost 775000 copies in Sweden and 100000 copies abroad (Annikas 2007, 10). Although the issue of the social status of the Meänkieli-speaking minority had long been a subject of much debate and work at the local and regional levels (Prokkola and Ridanpää 2011), the region aroused little national or international interest before Mikael Niemi’s breakthrough. Niemi was born in 1959 in Pajala, northern Sweden, and moved to Luleå in 1977, returning to Pajala in 1997 to continue his longlasting literary project, eventually published under the title Populärmusik, frän Vittula (2000). Niemi himself has a Meänkieli-speaking father and Swedish-speaking mother, and although Meänkieli was not spoken in Niemi's home and Niemi himself does not speak Meänkieli, the daily interaction between the two cultures has nonetheless been a concrete personal experience for him.

Populärmusik från Vittula is a humorous coming-of-age story focused on a Finnish/Meänkielispeaking young boy named Matti and his friend Niila growing up in Pajala, written with an eye for folk ethnography (see Havaste 2007). The story follows life in the 1960s and '70s in Tornedalen, and as the title of the book already alludes, the main focus is on the arrival of modernity in the boys' lives in the overtly conservative and backward Laestadian village of Pajala. 
The story is not just funny, but also sarcastic in several ways, the sarcasm stemming from pointed observations about the features characteristic of the local and regional culture, such as respect for religion (Laestadianism), patriarchalism and masculinity, and especially from stereotypes concerning Finnish/Meänkieli language and Finnishness with its all primitive qualities (see Eriksson 2010).

After being made into a film in 2004, the book's success as well as the national acknowledgement of the region increased remarkably, which was manifested for instance in the increased tourism in the region (see Ridanpää 2011). As a result of Niemi’s success, Tornedalen has become well-known and has stepped out of the margins. As Birger Winsa formulates it, "the authorship of Mikael Niemi is the key concept in this process of creating a cultural infrastructure that enhances minority identity and linguistic diversity and providing cultural events of the autochthonous minority for the tourists and local people and thereby promoting economic development" (2007, 279). At the same time, this cultural and artistic work has constituted a powerful narrative means for mediating the collective memory of the region (Prokkola 2008).

\section{TECHNIQUES FOR HEARING STORIES}

The methodological framework used in this paper is narrative inquiry. Narrative inquiry is commonly used to refer to a subset of qualitative research designs in which stories are used to examine and describe human action (Polkinghorne 1995). According to Prokkola (2009, 21), "[the] narrative method provides an in-depth examination of the multidimensionality and multivoiceness in the construction of self' (see also Lorimer 2003; Prokkola 2014). Participation in group discussions is a specific method through which the multiplicity of shared as well as contested narratives of spatial belonging and identity can be discovered (Price 2010). The focus in this study is on the identity narratives presented/performed in local group discussions, stories which are reflected against the societal background of Tornedalen as it has been narrated in Mikael Niemi's novel, as well as on the stories concerning how the novel has been received and adopted.

The empirical material of this study consists of 8 approximately 1-1.5-hour-long group discussions, conducted with 32 (15 male, 17 female) persons overall. The discussions were held in Haparanda, Övertorneå, Svanstein, Korpilombolo, Aapua and Pajala, between September 2015 and February 2016. As preliminary group cohesion is highly important in the context of minority identities, the people participating in the discussions were 1) already familiar with each 
other, indicating a certain level of trust, and 2) had a shared social bond. The selected participants represented people who are (inter-)actively working in several types of local associations and organizations operating around Tornedalen, some directly, some more indirectly, involved with the revitalization of Meänkieli: village associations, cultural associations, teachers from different levels of schools, local radio reporters and musicians. The purpose for choosing the focus groups from these various of organizations was to dissect how different communities comprehend their identities and its interconnections to humor in different, possibly controversial manners. The narrations of the discussants are analyzed anonymously and the names mentioned in the analysis have been changed.

The original purpose of the group discussions was not to delve into the influences of literature on local identity formation, but rather to discuss the nexus of local humor, minority language and cultural identity from a wider perspective. The research topic was briefly and openly introduced to the participants before the discussions, which naturally turned the discussion of local identities towards the forms of local humor. The outsized influence and relevance of Mikael Niemi's literature in this specific context was a research result of the study. The comments and stories of discussants are reflected against the regionalism and irony of Niemi's novel as well as against the wider sociopolitical and cultural history of the region.

\section{MIKAEL NIEMI'S VIT'TULA - THE REGION WHERE WE LIVE}

Conventionally it has been considered that the content of literary descriptions of regions stems from positive feelings of regionalism, as a form of love (Brace 1999). In this sense, regional identity comprises not all the features of the region, but rather those select few which people who identify themselves with it can be proud of. Niemi's novel is not anti-regionalist, but his style of using sarcasm to describe Tornedalen is overwhelming throughout the story. Niemi's Tornedalen is something to be ashamed of, a narration about what being different, in a negative sense, means in everyday life. The following excerpt is an example of how social circumstances, spatiality and its connection to identity become condensed in Niemi's work:

We gradually caught on to the fact that where we lived wasn't really a part of Sweden.

We'd just been sort of tagged on by accident. (...) We were different, a bit inferior, a bit uneducated, a bit simple-minded. We didn't have any deer or hedgehogs or nightingales. We didn't have any celebrities. We didn't have any theme parks. No traffic lights, no 
mansions, no country squires. All we had was masses and masses of mosquitoes,

Tornedalen-Finnish swear-words, and Communists.

Ours was a childhood of deprivation. Not material deprivation - we had enough to get by on - but a lack of identity. We were nobody. Our parents were nobody. Our forefathers had made no mark whatsoever on Swedish history. Our last names were unspellable, not to mention being unpronounceable for the few substitute teachers who found their way up north from the real Sweden. (...) We spoke with a Finnish accent without being Finnish, and we spoke without a Swedish accent without being Swedish.

We were nothing. (Niemi 2003, 48-9)

Although it has been argued that Mikael Niemi's narration is a far cry from traditional forms of regionalism (Carlson and Leppihalme 2010,170), the novel nevertheless centers directly on the question of what living in an internally othered region means for the people living there in their everyday lives. It could be argued that, according to Niemi's view, the key characteristic of the Tornedalian identity is lack of self-esteem, or even lack of identity itself (see Ridanpää 2014). Traditionally, regionalists have been appreciated for their ability to capture the true nature of the region, "as it is", through their art. One typical technique used by regionalists is to partly remold true stories based on local events. One of the key findings from the group discussions concerned the emphasis on the validity of Niemi's depictions. During discussions, it was emphasized how the characters in the novel were recognizable real-life persons, how their lives, including all the humorous incidents involved, are based on true events. Niemi's novel was considered to describe Tornedalian people "as they are". As Silk $(1984,167)$ describes, the connection of the text and reader can be understood either as an act of reading, consuming or becoming affected. In case of Niemi's novel, the particular emphasis should be paid on how literature produces effects on the reader. Niemi's novel produces regionalist affinity, but still there were, understandably, differences in terms of how the strongly sarcastic tone of the novel was received, as revealed in a discussion conducted in Korpilombolo:

Woman 1: I believe that Mikael has looked from outside and caught an image of the people and language, and he has been really good at depicting it. He has somehow approached it positively.

Man 1 (a participant who has close relatives with Niemi): But then there are those who are close to him (...) I have noticed that they don't like it. They don't want to hear about 
it. They change the subject or leave the house if people start talking about the book. They are kind of ashamed of it.

The people who participated in the discussions identify themselves with the book, as, for them, it was a narration about not only about 'us', but also 'me'. The previous excerpt also implies how there are conflicting opinions about the correct way to understand the book. As one man in a different group phrased this, "if you understand it in the right way, it is accurate". The question is, then, how can the Tornedalian reader identify her-/himself with a narration in which the people living in the region, 'we', are described as essentially 'nothing'? In order to find the above description somehow accurate and yet at the same time feel pride in it, one must have a certain sense of self-irony. Using humor to turn the stigma of being 'different' into a positive regional characteristic is a paradoxical theme constantly present throughout the work. Niemi's ironic and dark way of describing the sense of regional affinity was considered positive, but not by all the readers: when the joking was interpreted being personal, directed at ' $m e$ ', the function of text turns into an insult. Another question is, on what grounds the previous, quite serious description from Niemi's book can even be considered being humorous? For reader to find narratives humorous is a complicated combination of one's personality, identity, circumstances, and a variety of other factors, but in the case of Popularmusik fran Vittula Niemi makes it easier by launching the story with a hilarious narration. The book begins with a prologue, telling an out-ofcontext story of a narrator climbing the Thorong La mountain pass in central Nepal, kissing a Tiberian prayer plaque after reaching the summit and then getting his damp lips frozen into it:

Red. Blood. And pain so extreme I have to beat my head against the iron. It's impossible. My mouth is stuck as firmly as before.

$(\ldots)$

Then I pause. Feel for the mug that's hanging from my belt. Fill it full of pee, then pour the contents over my mouth. The urine trickles over my lips, starts the thawing process, and a few seconds later I'm free.

I've pissed myself free.

I stand up. My prayers are over. My tongue and lips are stiff and tender, but I can move them again. At last I can start my story.

The prologue is out of Tornedalian context, but it launches the contextual and interpretative framework within which a reader starts to give meanings for all the forthcoming descriptions of 
the region, including the dark and serious ones. The ironic nuances, that Niemi has in his narration concerning regional otherness, are thus easier for the reader to notice, but it still doesn't necessarily mean that his way of being ironic was conceived unconditionally as a positive thing. One man from Pajala, the village where most of the events in the book take place, describes this as follows:

Man 1: In Mikael's book there is a certain tone, which many, like me, did not like. It was a sarcastic, ironic tone against our people. It was not funny, it was a negative, sarcastic tone and it was noted here.

As exemplified here, one's sense of humor, for instance whether you appreciate irony or not, was a crucial factor with respect to how Niemi's book was received. Communicative irony always has a 'target', also called a 'victim' (Hutcheon 1994, 15), and the spectre of becoming 'victimized' is an understandable motive for not associating oneself with the narrative. Another topic that divided the opinions of readers concerned one word in the book title, "Vittula". As the novel's main location "Vittula" is Finnish/Meänkieli toponym, Niemi had occasion to translate its meaning for the target audience, Swedish readers:

Our district was known locally in Finnish as Vittulanjänkkä, which means something like Cuntsmire. It's not clear how the name originated, but it probably has to do with the great number of babies being born here. There were five children in some of the houses, sometimes even more, and the name became a sort of crude tribute to female fertility.

(Niemi 2003, 12)

The novel was originally written in Swedish, for Swedes, so the target audience would otherwise be blind to the coarse nature of the title. For Finnish- or Meänkieli-speaking readers the situation is completely different. Even seeing the book's title might make the reader laugh - it is not usual to see "cunts" in place names - or alternatively, feel more or less embarrassed, depending on the reader's sense of humor. As one woman described,

Woman 1: For so many Finns it is so difficult to utter the title. I have one colleague from the Finnish side, who says (s)he cannot speak the title of the book. It is so difficult to utter it. And here we wonder, 'what's wrong with that?' 
Woman 1: That place was called 'Vittula', since there were so many children. [laughter]

Man 1: People were not allowed to move there before they had several children.

$(\ldots)$

Woman 1: But it is partly that way for me too, that when I'm in Finland and if we start talking about it, (I say) 'that novel, Mikael Niemi's... that... that novel, the novel, that Mikael Niemi novel!' [laughter] Like you don't dare to say it aloud (the name).

Woman 2: I never think about what it means.

Woman 1: It depends on the context, relations, about whom you are with.

As Niemi together with discussants explain, the name Vittula origins back to female fertility which, in turn, origins back to Laestadianism, a widely spread revival movement of Lutheran church founded in Tornedalen in the middle of the 19th century by a Swedish Sami pastor Lars Levi Laestadius (10 January 1800 - 21 February 1861). The most important religious guideline for a Laestadian woman is a belief that a child is a gift from God. In addition, other social norms and codes of Laestadianism consists of the beliefs such as that rhythmic music, alcohol, makeup, TV, birth control, and pre-marital sex are forbidden by God. Niemi turns the norms of Laestadianism into identity markers for Tornedalian life, parodying them with dark humor throughout the book:

Niila's dad was called Isak and came from a big Laestadian family. Even as a little boy he'd been dragged along to prayer meetings in the smoke-filled hut where dark-suited smallholders and their wives in knotted headscarves sat bottom to bottom on the wooden benches. It was so cramped that their foreheads hit against the backs of those in front whenever they were possessed by the Holy Spirit and started rocking back and forth as they intoned prayers. (Niemi 2003, 27)

'Vittula' as a term is thus not just 'a sort of crude tribute to female fertility', as Niemi describes it, but instead refers to the wider sociopolitical and cultural history of the region. Respectively, finding previous kinds of narratives insulting and refusing to laugh at them, is also socially conditioned. Although Laestadianism is defined as an identity marker for the region, if the reader doesn't have personal Laestadian background, being 'self-ironic' is understandably relatively easy. Self-teasing bonds participants and develops relational group identity, but not without the knowledge about how far one can go with joking on certain topics (see Boxer and Cortés-Conde 1997, 292). However, for some readers the coarse nature of book's title may influence whether 
they are even willing to open the cover or not. This offers a convenient way to divide people into two groups: those who recognize the book's status as a regional narrative and those who reject the whole idea based on their own personal principles. No matter how precise and lively Niemi's regional descriptions are, some participants perceived that for some readers one coarse word made the whole narrative unacceptable. The unique role of the title itself was also brought up in a discussion between two Finnish women, who are active in a local Christian choir:

Woman 1: (laughing) It was so obscene - that word - that I could not start reading it.

Woman 2: The novel's name?

Woman 1: Yes.

Woman 2: Come on! They have streets named that in Pajala.

Woman 1: So they have, I've heard. Horrible. Absolutely horrible. I just cannot tolerate it. In my opinion that goes beyond that pale and I won't have anything to do with it. $(\ldots)$

Woman 2: One thing that was funny about Popular Music was that it did not speak offensively about Laestadians.

Woman 1: I have seen the film. (...) I got the image that the film was cleaned up. Maybe it was. I don't know because I have not read the novel. But I watched it so that I was close to the kitchen. I needed to flee to the kitchen for some scenes. (...) There are so many beautiful things here, there is so much that is lovely and good and sweet and pleasing and all the delightful words there are, so there's no need for that.

As implied, the coarse nature of the title may put off some readers, but on the other hand, for some readers, especially local ones, the coarse language is an element which crystallizes one characteristic of the region's identity. During the discussions it was several times mentioned how Finns ('them') are horrified by any mention of such place names whereas local people are unperturbed by it. For locals using such language in daily conversations is a natural part of everyday life, even an identity marker that characterizes local heritage. These place names may sound coarse to 'others', but for local people they sound normal and operate as reminders of local history and as a part of people's narrative identity.

What was particularly interesting to discover was that almost every time that the coarse nature of Meänkieli was brought up, a certain tone of self-conscious pride was noticeable. The existence of a place name such as Vittula is local knowledge - heritage - that is familiar only to local people but shared with the rest of the world by Niemi. 'We were becoming famous' was actually 
an important factor when the content and (regional) impact of the book were discussed.

Although the negative overtones of the book were also criticized, for some participants the (commercial) success of the book meant that being from this unique periphery was something to be proud of:

Woman 1: It was published the same year when the minority language act came into force.

Woman 2: Really?

Woman 1: Yes, the year 2000, yes.

Man 1: It was extremely important. And then people of my age came to be proud of where we were from, like "I am from the Texas region" [nickname of one small district in the novel]. If we visited festivals in southern Sweden or somewhere else, we'd say like "I am from Pajala."

Although the remoteness of a place can itself be a factor that strengthens the sense of belonging (see Bocco 2016), in the case of Pajala the pride in being marginal originates from the success of the novel. The novel is an identity narrative of a national minority living in a marginal region, but the success turns into a meta-narrative that makes it easier for a local one to identity oneself with the content of the novel, that is, of being othered. Secondly, although publishing the book on the same year when the Meänkieli minority language act came into force was a coincidence, it launched a new interpretative layer for how the theme of minority language and its connection to regional identity were to be approached. In addition, as mentioned, for the language activists this coincidence was extremely important. This also had an influence on local tourism entrepreneurs, who made all efforts to take advantage of the publicity of the work. Pajala was turned into a 'literary place', an attraction for literary tourists (see Herbert 1995; 2001). Tourists were guided to walk in the footsteps of, if not actually Mikael Niemi, then rather the protagonists of the novel (Ridanpää 2011). From local tourism information spots visitors were able to pick up humorous maps which included a sketch of Pajala' street plan, adorned with passages from the book and funny drawings depicting related scenes from the book (Figures 1). In an image on the bottom of the map, at the locations of the old school house (Gamla Skolan), features a drawing of a tired teacher standing together with three poor-looking children with a passage from the novel:

One overcast morning in August the bell rang, and I started school. Class one. Twenty kids with loose milk teeth and knuckles covered in warts. Some had speech defects, others wore glasses, many spoke Finnish at home, several were used to receiving a good beating if 
they stepped out of line, nearly everybody was shy and came from working-class homes, and knew from the start they didn't belong here. (Niemi 2003, 44)

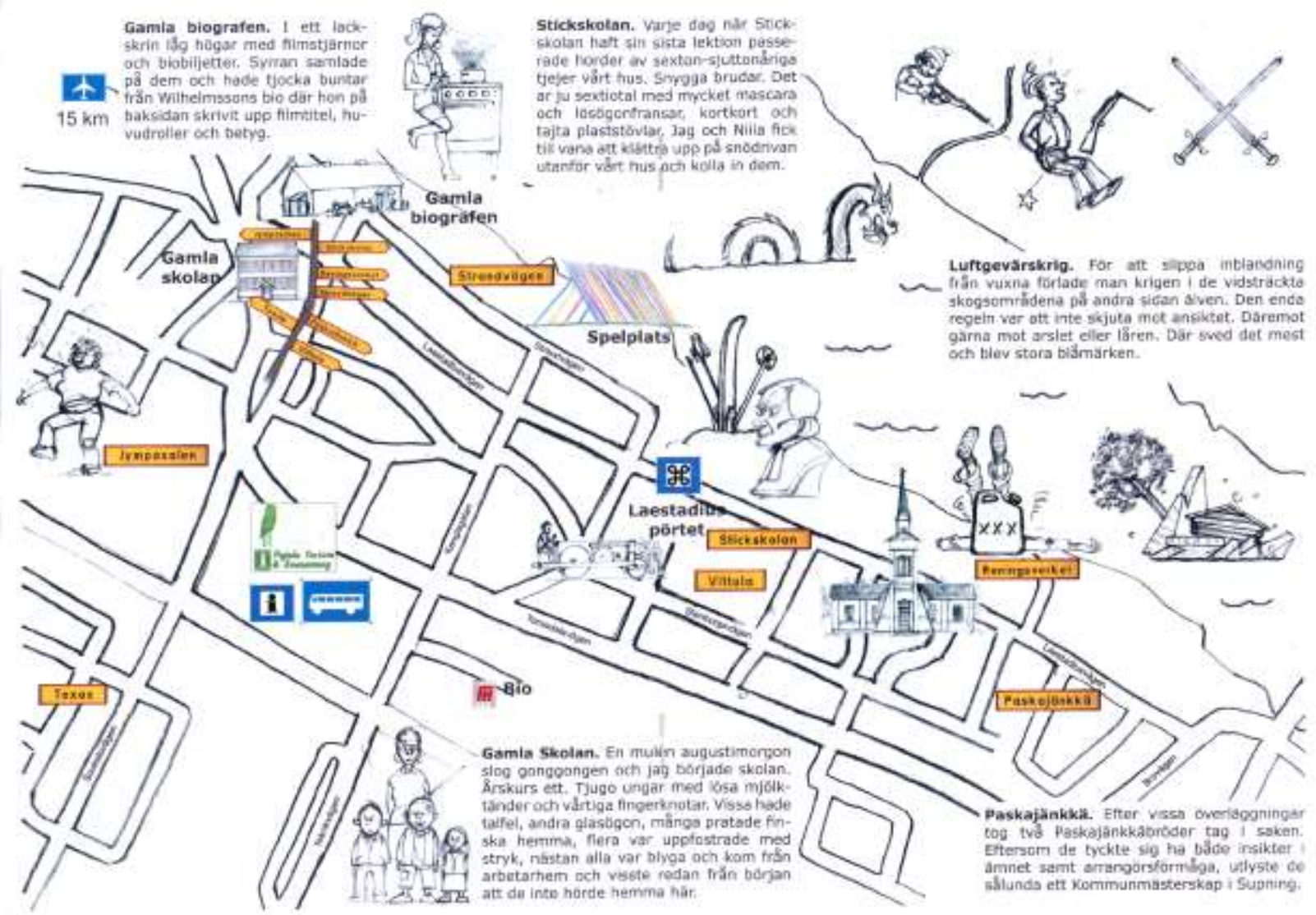

FIGURE 1. The map sketch from the Pajala tourism promotion brochure, including quotes from Populärmusik frän Vittula. Niemi personally helped with the design of the map. (Vittula: En live-laing uppförsbacke, som vägen mellan Pajala och Muodoslompolo 2008, leaflet illustrated by Hans-Peter Enbuska. Used by permission of Tornedalens Media AB)

Niemi's text is used as a tool for place promotion, though it is far from promotional. On the one hand, this illustrates how in marginal regions all possible opportunities for promotional advantages must be seized upon. As one male participant, who had earlier worked for the municipality of Pajala when the book was published, commented in a discussion:

Man 1: It was very dark times then, there had been out-migration for several decades and the causes for happiness were not that many, so there were two things that could be used 
in presentations to get sympathy. One was Mikael's book, from which you could pick up stories, and the other was Charlotte Kalla [an Olympic skiing champion].

What is interesting and notable in way tourism entrepreneurs took advantage of Niemi's humor, was that the most negative aspects of it, the self-ironic overtones, were cited for promotional purposes. The people of the region are very aware of being marginal, and along with the success of Niemi's work, they can, in a sarcastic manner, flaunt it proudly. For example, the Pajala tourism brochure is sarcastically entitled: "Vittula: A lifelong uphill climb, like the road between Pajala and Muodoslompolo." This title refers to a passage from the book in which the life of a Laestadian person is allegorically described as a desperate walk in the middle of wilderness from Pajala to the northernmost village in the municipality, Muodoslompolo. It would probably be an overstatement to argue that self-irony is embedded in how people in Tornedalen conceive of themselves, but nonetheless the content of humor and self-irony is constantly present, when discussing with locals about the identity of Tornedalen.

Although local tourism entrepreneurs took full advantage of Niemi's publicity, his status as a regionalist working for the benefit of the region was also questioned by other local cultural actors. Although Niemi's role in gaining recognition for the region has been crucial, in group discussions it was occasionally brought up how the author Bengt Pohjanen (1944-) still stands as the helmsman for the revitalization of Meänkieli culture and language. Pohjanen has written the first novel to use Meänkieli as a literary language, Kasaland in 1984, a grammar of Meänkieli in 1996 and has been the leader in the process of linguistic emancipation in numerous ways. Against this background it was predictable that the relationship of Niemi and Pohjanen was brought up:

Man 1: And one already well-known author from here, Bengt Pohjanen, got offended. And between them there started a hell of a fight and it's still going on. It is said that it was because this snotty youngster came and threatened his position, but there was also that tone, that his whole image [of the region] was demeaning.

Pohjanen's "payback" on Niemi was realized in the short film Fylla moppe (2003). Niemi's interpretation was that Pohjanen's film was about Niemi's family, who were presented in an insulting manner, for instance through stories of his father's actions as a moonshiner (Mäkinen 2003). Pohjanen, respectively, denied that the events in the film were based on Niemi's family history. At the premiere event Niemi, instead of congratulating Pohjanen, threw a cream cake 
into his face, which received wide publicity in Scandinavia. Ever since, this 'pie' episode has been

laughed at by local people and related as a hilarious example of how serious the work of regional activism is for the activists and artists themselves. Local stories are essential material for regionalists in their creative work, but as the group discussions exemplified, local stories can also hurt people and cause anger and rejection, if they come too close to individual real-life events or if mockery turns personal. And isn't it ironic that the same thing happened to the ironist himself: when the story came too close, the reader's response was anger and rejection. The pie episode was described in several group discussions and it seems it has turned into a new humorous narration for the regional identity of Tornedalen.

\section{CONCLUSIONS}

Generally, literary regionalism is expected to uphold and promote the positive attachment and love for the region, the "we-feelings", which makes the use of irony and dark humor extremely difficult, but also crafty tools for using. The use of irony in regionalist narratives makes selfidentities complicated, sometimes strengthening the sense of belonging, while occasionally causing disharmony within the groups, in terms of how people conceive themselves. As Niemi's case proved, the success of the book has influence on how people in the region receive the book and accept the dark and ironic narrative of it, in collaborative manner, as an updated version of "who we are". Dark humor may thus have its positive impact, especially in marginal regions, and authentic descriptions may give rise to local people's self-esteem, but not necessarily. The reader's sense of humor may be stretched too far when they notice being the object of a joke.

This study of Mikael Niemi's novel and how it has been conceived of by the Tornedalian people exemplifies how complicated the relationships between writer and reader and their connection to narrative identities are. Literary regionalism is in a key position regarding the establishment of regional identities, since through literary works shared meanings are kept alive. Although it has been recently emphasized, how "stories have a purpose beyond evidence, beyond the author, and beyond the empirical situation from which they are derived" (Mitch 2016, 132), it is important to underscore that regionalist stories are true stories about the life experiences of true people who have lived or are still living in the region. In that sense the author and his/her novels function as a medium through which identity narratives are told and narrative identities re-established. The chain of communication between sender, message and receiver the writer, the book and the reader - takes place within particular sociocultural and regional 
context, while the novel works as a mirror against which self-conception and senses of belonging become reflected, possibly strengthened or altered. In that way the novel and its content is attached - and not least because of the huge success of the novel - as a new layer on the identity of the region. The other impact that Niemi's novel has made is that, encouraged by the success of the book, several new novelists from the region, new regionalists, have started publishing their work.

Humor is an integral part of shared identities so reflecting on the regional self-conception through humorous text happens naturally. The shared conceptions of 'us' are often told through the old humorous stories and jokes, and retold through the stories of modern regionalist literature along with all the contextual (social, cultural, political, ...) elements involved. Regional identities are always multiform and overlapping and as seen here, for some the ironic take on the local identity and people living in the region is an insult, a distorted reflection of what 'we' truly are. These experiences of being insulted are individual, but one question that rises is whether the sense of humor, particularly self-irony and ability to handle it, is always a matter of individual viewpoint, or if there is a socially shared and culturally conditioned sense of humor. The narrations of "who we are" are not always shared. Nevertheless, regionalist literature, even dark and ironic one, plays a role in strengthening and re-establishing regional belonging and selfperception.

\section{ACKNOWLEDGEMENTS}

Research was financially supported by Kone Foundation - Finland.

\section{REFERENCES}

Annikas, A. 2007. Fucking Vittula. Kristianstad: Kristianstads boktryckeri.

Atluri, T. 2011. Lighten up?! Humour, Race, and Da off colour joke of Ali G. Media, Culture and Society 31 (2): 197-214.

Barbe, K. 1995. Irony in Context. Amsterdam: John Benjamins Publishing Company.

Bocco, G. 2016. Remoteness and remote places. A geographic perspective. Geoforum 77, 178-81.

Boxer, D. and F. Cortés-Conde 1997. From bonding to biting: Conversational joking and identity display. Journal of Pragmatics 27 (3): 275-94. 
Brace, C. 1999. Finding England everywhere: regional identity and the construction of national identity, 1890-1940. Cultural Geographies 6 (1): 90-109.

Cameron, E. 2012. New geographies of story and storytelling. Progress in Human Geography 36 (5): 573-92.

Carlson, S. and I. Leppihalme 2010. Mikael Niemi, Pohjoisen Garcia Marques [Mikael Niemi, the Garcia Marques of north]. In Pohjois-Suomen kirjallisuushistoria [Literary history of northern Finland], ed. S. Carlson et. al., 168-71. Helsinki: Suomalaisen Kirjallisuuden Seura.

Darby, H. C. 1948. The Regional Geography of Thomas Hardy's Wessex. Geographical Review 38 (3): 426-43.

Davies, C. 1990. Ethnic Humor around the World: A Comparative Analysis. Bloomington, Ind.: Indiana University Press.

Delph-Janiurek, T. 2001. (Un)consensual conversations: betweenness, ‘material access', laughter and reflexivity in research. Area 33 (4): 414-21.

Elenius, L. 2001. Både finsk och svensk modernisering, nationalism och språkförändring $i$ Tornedalen 18501939 [Both Finnish and Swedish modernization, nationalism and language change in the Torne Valley 1850-1939]. Umeå: Umeå universitet.

Eriksson, M. 2010. (Re)producing a periphery: Popular representations of the Swedish North. Umeå: Department of Social and Economic Geography.

Gilbert, E. W. 1960. The idea of the region. Geography 45 (3): 157-75.

Gilmartin, M. and B. Migge 2015. Home stories: immigrant narratives of place and identity in contemporary Ireland. Journal of Cultural Geography 32 (1): 83-101.

Havaste, P. 2007. Mikael Niemi. In Ulkomaisia suosikekikirjailijoita Marques [Foreign favourite novelists], ed. I. Loivamaa, 134-37. BTJ: Helsinki.

Heith, A. 2012. Ethnicity, Cultural Identity and Bordering : A Tornedalian Negro. Folklore 52: 85-108.

Herbert, D., ed. 1995. Heritage, Tourism and Society. London: Mansell. -. 2001. Literary Places, Tourism and Heritage Experience. Annals of Tourism Research 28 (2): 312-33.

Hettner, A. 1907. Grundž̈̈e der Länderkunde [The principles of regional geography]. Leipzig: Spamr.

Hones, S. 2008. Text as it happens: Literary geography. Geography compass 2 (5): 1301-17.

- 2014. Literary geographies: narrative space in Let the great world spin. New York: Palgrave Macmillan. 
Hult, F. M. 2004. Planning for Multilingualism and Minority Language Rights in Sweden. Language Policy 3 (2): 181-201.

Hutcheon, L. 1994. Irony's edge: the theory and politics of irony. London: Routledge.

Jones, M. 2009. Phase space: Geography, relational thinking, and beyond. Progress in Human Geography 33 (4): 487-506.

Júlíusdóttir, M. 2007. Culture, cultural economy and gender in processes of place reinvention. In Place Reinvention in the North - Dynamics and Governance Perspectives T. Nyseth and B. Granås, eds., 39-53. Stockholm: Nordregio.

Knuuttila, S. 1992. Kansanbuumorin mieli: Kaskut maailman kuvan aineksena [The spirit of folk humour: Funny stories as consituents of world picture]. Helsinki: Suomalaisen kirjallisuuden seura.

Lorimer, H. 2003. Telling small stories: spaces of knowledge and the practice of geography. Transactions of the Institute of British Geographers 28 (2): 197-217.

Mäkinen, L. 2003. Bengt Pohjaselle kakku naamaan [A cake into Bengt Pohjanen's face]. Kaleva February 14. Accessed October 10 2017. http://www.kaleva.fi/uutiset/kulttuuri/bengtpohjaselle-kakku-naamaan/494228/.

Niemi, M. 2003. Popular Music from Vittula. Translated from the Swedish by Laurie Thompson. New York: Seven Stories Press.

Norrick, N.R. and D. Chiaro, D., eds. 2009. Humor in Interaction. Amsterdam: John Benjamins B.V.

Noxolo, P. and M. Preziuso 2013. Postcolonial imaginations: Approaching a "fictionable" world through the novels of Maryse Condé and Wilson Harris. Annals of the Association of American Geographers 103 (1): 163-79.

Paasi, A. 1984. Alueellinen identiteetti ja siihen vaikuttavat tekijät - esimerkkinä alueellinen kirjallisuus [Regional identity and influencing factors - example regional literature]. Terra 96 (2): 113-20.

Paasi, A. and J. Metzger 2017. Foregrounding the region. Regional Studies 51 (1): 19-30.

Palmer, J. 1994. Taking Humour Seriously. London: Routledge.

Paterson, J. H. 1965. The Novelist and his Region: Scotland through the Eyes of Sir Walter Scott. Scottish Geographical Magazine 81 (3): 146-52.

Polkinghorne, D. E. 1995. Narrative configuration in qualitative analysis. International Journal of Qualitative Studies in Education 8 (1): 5-23.

Price, P. 2010. Cultural geography and the stories we tell ourselves. Cultural Geographies 17 (2): 203-10. 
Prokkola, E. 2008. Border Narratives at Work: Theatrical Smuggling and the Politics of Commemoration. Geopolitics 13 (4): 657-75.

2009. Unfixing borderland identity: Border performances and narratives in the construction of self. Journal of Borderlands Studies 24 (3): 21-38.

- 2014. Using Narrativity as a Methodological Tool. ACME: An International E-Journal for Critical Geographies 13 (3): 442-49.

Prokkola, E. and J. Ridanpää 2011. Following the plot of Bengt Pohjanen’s Meänmaa:

Narrativization as a process of creating regional identity. Social \& Cultural Geography 12 (7): 775-91.

Ridanpää, J. 2010. A masculinist northern wilderness and the emancipatory potential of literary irony. Gender, Place \& Culture 17 (3): 319-35.

- 2011. Pajala as a literary place: in the readings and footsteps of Mikael Niemi. Journal of Tourism and Cultural Change 9 (2): 104-18.

-2014. Politics of literary humour and contested narrative identity (of a region with no identity). Cultural Geographies 21 (4): 711-26.

Rose, M. 2016. A place for other stories: Authorship and evidence in experimental times. GeoHumanities 2 (1): 132-48.

Rycroft, S. and R. Jenness 2012. JB Priestley: Bradford and a provincial narrative of England, 1913-1933. Social \& Cultural Geography 13 (8): 957-76.

Saunders, A. and J. Anderson (2015) Relational Literary Geographies: Co-Producing Page and Place. Literary Geographies 1 (2): 115-19.

Sheftel, A. 2012. 'Monument to the international community, from the grateful citizens of Sarajevo': Dark humour as counter-memory in post-conflict Bosnia-Herzegovina. Memory Studies 5 (2): 145-64.

Silk, J. 1984. Beyond text and literature. Environment and Planning D: Society and Space 2: 151-78.

Terrion, J. L. and B. E. Ashforth 2002. From 'I' to 'We': The Role of Putdown Humor and Identity in the Development of a Temporary Group. Human Relations 55 (1): 55-88.

Tomaney, J. 2007. Keeping a Beat in the Dark: Narratives of Regional Identity in Basil Bunting's Briggflatts. Environment and Planning D: Society and Space 25 (2): 355-75.

- 2015. Region and place II: Belonging. Progress in Human Geograpby 39 (4): 507-16.

Tuan, Y.-F. 1975. Place: An Experimental Perspective. Geographical Review 65 (2): 151-65.

Vaattovaara, J. 2009. Meän tapa pubua: Tornionlaakso pellolaisnuorten subjektiivisena paikkana ja murrealueena [Our way to talk: The Torne Valley as a subjective place and dialectal area for the youth in Pello]. Helsinki: Suomalaisen Kirjallisuuden Seura. 
Vainikka, J. 2012. Narrative claims on regions: prospecting for spatial identities among social movements in Finland. Social \& Cultural Geography 13 (6): 587-605.

Vittula: En liveläng uppförsbacke, som vägen mellan Pajala och Muodoslompolo[Vittula: A lifelong uphill climb, like the road between Pajala and Muodoslompolo] -tourism leaflet 2008. Pajala: Tornedalen Media ab \& ELEX språkbyrå.

Vucetit, S. 2004. Identity is a Joking Matter: Intergroup Humor in Bosnia. Spaces of Identity 4 (1): $7-34$.

Winsa, B. 2005. Language policies: instruments in cultural development and well-being. International journal of circumpolar health 64 (2): 170-83.

-2007. Social capital of indigenous and autochthonous ethnicities. In International Handbook of Research of International Entrepreneurship, L. Dana and R. B. Anderson, eds., 257-86. Chelterham: Edward Elgar Publishing.

Yap, E. X. 2011. Readers-in-conversations: a politics of reading in literary geographies. Social \& Cultural Geography 12 (7): 793-807.

JUHA RIDANPÄÄ is a Senior Research Fellow in the Geography Research Unit at Oulu University, Oulu, Finland. E-mail: juha.ridanpaa@oulu.fi. His research interests include the geographical studies of humor, narrative studies, literary geography, popular geopolitics and postcolonial studies. 